\title{
Comparison of Work-Related Stress between Emergency Medicine and Internal Medicine Doctors: A Single Center Cross-Sectional Study
}

\author{
Acil Tıp ile İç Hastalıkları Hekimleri arasındaki İş ile Illgili Stres Durumunun \\ Karşıllaştırılması: Tek Merkezli Kesitsel Çalışma
}

\section{Kurtulus ACIKSARI $\odot$, Hasan Turan KARATEPE $\odot$}

\begin{tabular}{l|l} 
Ethics Committee Approval: This study was approved by the Istanbul Medeniyet University & $\begin{array}{l}\text { Cite as: Aciksari K, Karatepe HT. Comparison of work-related stress between emergency } \\
\text { medicine and internal medicine doctors: A single center cross-sectional study. Medeni- } \\
\text { Gotepe Training and Research Hospital Ethic Committee for Clinical Studies (22 March 2016, } \\
\text { 2016/0067). }\end{array}$ \\
Conflict of interest: The authors declare that they have no conflict of interest. & \\
Funding: None. \\
Informed Consent: Was taken from all participants.
\end{tabular}

\begin{abstract}
Objective: In this study we aimed to examine and compare the stress levels and the factors affecting stress levels of physicians working in Emergency Medicine (EM) and Internal Medicine (IM) Departments.

Method: This is a cross-sectional study performed in a research and training hospital. The study population consisted of 39 physicians. Professional Life Stress Scale (PLSS), Beck Anxiety Inventory (BAI), Beck Depression Inventory (BDI) and Acceptance and Action Questionnaire-II (AAQII) were used.

Results: Thirty-nine physicians (female 56.4\%; mean age $32.6 \pm 6.8$ years) included in analysis. They were from $E M(n=19 ; 48.7 \%)$, and IM ( $n=20 ; 51.3 \%)$. Twenty-six (66.7\%) participants had a score of 16-30 points indicating a moderate degree of stress in their professional life. The BAI and $B D I$ scores of the participants ranged from $O$ to 36 (mean, 8.4 4.9 ) and $O$ to 29 (mean, 7.6 \pm 5.9 ), respectively, which indicated that the participants were below the psychopathological limits in terms of anxiety and depressive symptoms. AAQ-II scores were found to be significantly lower in emergency physicians $(p=0.049)$ indicating that they had a lower level of experiential avoidance than others. Also, AAQ-II scores were found significantly lower in those who had children ( $p=0.028$ ).

Conclusion: Working in EM departments for longer periods is associated with higher stress levels while increases the ability to cope with stress. Our study shows that having children is related with decrease in experiential avoidance, hence higher levels of psychological flexibility. Any significant differences were not found between the groups in terms of PLSS, BAI and BDI scores.
\end{abstract}

Keywords: Work-related stress, anxiety, psychological flexibility, physician, emergency

öz

Amaç: Bu çalıșmada, Acil Tıp ile İç Hastalıkları bölümlerinde çalıșan hekimlerin psikolojik iyilik halleri ile stres düzeylerinin incelenerek karşılaştırılması amaçlanmıştır.

Yöntem: Bu araştırma, bir eğitim ve araştırma hastanesinde yapılan kesitsel bir çalıșmadır. CaIıșmaya 39 hekim katıldı. Olçeklendirmelerden Profesyonel Yașam Stres Olçeği (PYSO), Beck Anksiyete Envanteri (BAE), Beck Depresyon Envanteri (BDE) ve Kabul Eylem Formu-II (KEF-II) kullanildı.

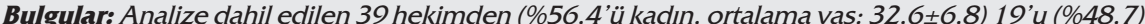
acil ve 20'si $(\% 51,3)$ iç hastalıkları branşındaydı. Katılımcıların \%66,7'sında (N=26) PYSÖ 16-30 puan aralığında hesaplanmıştır ki bu değer aralığı meslek yașamlarında orta düzeyde streste olduklarını göstermektedir. BAE ve BDE skorları sırasılla 0-36 (ortalama, 8,4 $\pm 8,9$ ) ve 0-29 (or-

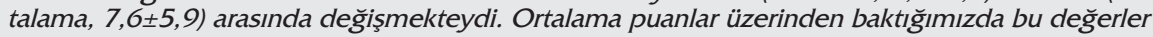
katıımcıların anksiyete ve depresif semptomlar açısından psikopatolojik sınırın altında olduklarını işaret etmektedir. Acil uzmanlarında KEF-II skorlarının anlamlı olarak düșük bulunması $(p=0,049)$ yaşantısal kaçınmanın sadece bu grupta düşük olduğunu göstermektedir. Ayrıca çocuk sahibi olanların KEF-II skorlarının düșük olduğu saptanmıștır $(p=0,028)$.

Sonuc: Uzun süreli acilde çalışmak, stresle başa çıkma yeteneğini arttırırken, daha yüksek stres seviyelerine neden olmaktadır. Çalışmamızda çocuk sahibi olmanın yaşantısal kaçınmada azalma ve psikolojik esneklikte artma ile birlikte olduğu görülmüștür. Bununla birlikte, gruplar arasında PYSÖ, BAE ve BDE skorları açısından anlamlı bir fark bulunmamıştır.

Anahtar kelimeler: İs stresi, anksiyete, psikolojik esneklik, hekim, acil

(c) Copyright Istanbul Medeniyet University Faculty of Medicine. This journal is published by Logos Medical Publishing.

Licenced by Creative Commons Attribution-NonCommercial 4.0 International (CC BY-NC 4.0)
Received: 31 July 2019 Accepted: 22 September 2019 Online First: 28 February 2020

Corresponding Author: K. Aciksari

ORCID: 0000-0002-0749-4651 Istanbul Medeniyet University Goztepe Training and Research

Hospital, Department of Emergency Medicine, Istanbul, Turkey

drkurtulus@yahoo.com

H.T. Karatepe ORCID: 0000-0002-6394-8312 Istanbul Medeniyet University Goztepe Training and Research Hospital, Department of Psychiatry, Istanbul, Turkey 


\section{INTRODUCTION}

Stress can be expressed as an emotional experience that one cannot overcome the stressor with his/her ability so as to find individual or social solutions to problems encountered during his/her life. Stress is a psychological condition that affects the individual's physiological and psychological wellbeing and negatively affects his/her behaviors, productivity and relationships with other people ${ }^{1}$. A modest stress might be performance enhancing; while stress that is too intense to cope with might have negative effects on the individual and his/her work performance ${ }^{2}$. Burnout and stress are widespread problems experienced by healthcare workers $^{3}$. Exposure to stress factors in the workplace has been associated with a number of adverse physical and mental health problems ${ }^{4}$. Chronic job stress in emergency health care workers is associated with occupational dissatisfaction, physical fatigue, burnout and posttraumatic stress symptoms ${ }^{5-8}$.

Stress in critical situations that can be observed in patient care in emergency department workers is defined as situations in which emergency service personnel may produce extraordinary strong emotional reactions that may be encountered in many events effecting their professional skills at or after the scene? ${ }^{9}$. For every operational person, stress in addition to affecting the individual's health, well-being and success in the job, may also reduce the quality of patient care even results in avoidance or cessation of work ${ }^{10,11}$. Occupational dissatisfaction and burnout syndromes are more common among healthcare workers, especially among staff in health care departments where they work in direct contact with patients ${ }^{12}$. For this reason, we included the emergency physicians and internal medicine physicians who were in contact with patient groups that had relatively higher expectations from treatment. The present study aimed to examine and compare the stress levels with psychological well-being of physicians working in Emergency Medicine (EM) and Internal Medicine (IM) Departments. In addition, the factors affecting stress levels were assessed.

\section{MATERIALS and METHODS}

This study was approved by the Istanbul Medeniyet University Goztepe Training and Research Hospital Ethic Committee for Clinical Studies (22 March 2016, 2016/0067).

\section{Participants}

All the physicians working in Departments of both Emergency Medicine (EM) and Internal Medicine (IM) were contacted personally. Information sheets and consent forms were given to them individually. All face-to-face interviews were conducted in a quiet room to help filling in the questionnaires. All the residents and specialists accepted to participate in the study. The population of the study consisted of 39 physicians. Nine EM specialists, $10 \mathrm{EM}$ residents were working in EM, and $10 \mathrm{IM}$ specialists and $10 \mathrm{IM}$ residents were working in IM.

\section{Questionnaires}

Sociodemographic data form: A semi-structured questionnaire was designed by the researchers considering the situations that might affect stress levels such as age, gender, marital status, number of children and factors that may affect working conditions such as number of night shifts, skipping meals, working environment status, hygienic conditions of the toilets and safety security.

Professional Life Stress Scale (PLSS) developed by David Fontana consists of 22 questions. It includes many different variables such as personality perception of others, optimistic life, individual and professional satisfaction, harmony with the professional condition, and so forth. The total score is 60 and is classified as follows: 0-15: Stress is not a problem in one's life; 16-30: Moderate stress which can be sensibly reduced; 31-45: Stress is obviously a problem and needs treatment; 46-60: stress is a significant problem and intervention is being required ${ }^{13}$. 
Beck Anxiety Inventory (BAI): BAI is a 21 -item, self-report scale and each item is rated on a 4-point scale between 0 and $3^{14}$. The validity and reliability study of the Turkish version was performed by Ulusoy et al. ${ }^{15}$ BAI scores indicate various degrees of severity as follows: 0-9 points no/ minimal anxiety; 10-16 points, mild anxiety, 1729 points, moderate anxiety, and 30-63 pointys, severe anxiety.

Beck Depression Inventory (BDI): The BDI is a 21 item, self-report scale which is widely used indicator of severity of depression with a sensitivity and specificity of $81 \%$ and $92 \%$, respectively ${ }^{16}$. Each item rates symptom severity on a 4-point scale between 0 and 3 . Total BDI scores vary between 0 and 63 and higher scores point to an increase in depressive mood. According to BDI scores, 0-13 indicates minimal depression, 14-19 indicates mild depression, 20-28 points indicates moderate depression, 29-63 indicates severe depression. The reliability and validity study of Turkish version was performed by Hisli ${ }^{17}$.

Acceptance and Action Questionnaire-II (AAQ-II): AAQ-II is a 7-item, self-report scale that has been developed for assessing the experiential avoidance and psychological inflexibility levels. The responses to items were scored from 1 (never true) to 7 (always true) points. Higher scores received from the scale show higher levels of psychological inflexibility, thus increase in experiential avoidance. The validity and reliability study of its Turkish version was performed by Yavuz et al. ${ }^{18}$.

\section{Statistical analysis}

Data analysis was performed by using the IBM SPSS Statistics for Windows version 25 (IBM Corp., Armonk, NY, USA). Descriptive values of the obtained data were given as percentages and quartiles for categorical variables and as mean and standard deviation for numerical variables. The agreement of the scale scores to the normal distribution was examined by Kolmogorov-Smirnov test. Since the scale scores did not show normal distribution, Mann-
Whitney U test or Kruskal-Wallis test were used for group comparisons. Results that were found to be significant according to Kruskal-Wallis test were examined by post-hoc Dunn test. The results were evaluated within confidence interval of $95 \%$ and at a level of statistical significance of $\mathrm{p}<0.05$.

\section{RESULTS}

A total of 39 physicians participated in the study. Thirty-nine physicians included in the analysis,

Table 1. Sociodemographic characteristics of the participants.

\begin{tabular}{|c|c|c|c|}
\hline & $\begin{array}{l}\text { Emergency } \\
\text { Medicine } \\
\text { Doctors }\end{array}$ & $\begin{array}{l}\text { Internal } \\
\text { Medicine } \\
\text { Doctors }\end{array}$ & $\mathbf{p}$ \\
\hline Characteristics & $(n=19)$ & $(n=20)$ & \\
\hline Age, year* & $33.2 \pm 6.8$ & $32 \pm 6.2$ & 0.604 \\
\hline \multicolumn{4}{|l|}{ Gender $^{\mathrm{a}}$} \\
\hline Female & $11(57.9 \%)$ & $11(55 \%)$ & \multirow[t]{2}{*}{0.860} \\
\hline Male & $8(42.1 \%)$ & $9(45 \%)$ & \\
\hline \multicolumn{4}{|l|}{ Marital status ${ }^{a}$} \\
\hline Married & $9(47.4 \%)$ & $10(50 \%)$ & \multirow[t]{2}{*}{0.820} \\
\hline Single & $10(52.6 \%)$ & $10(50 \%)$ & \\
\hline \multicolumn{4}{|l|}{ Number of child(ren) ${ }^{a}$} \\
\hline No child & $12(63.2 \%)$ & $13(65 \%)$ & \multirow[t]{3}{*}{0.163} \\
\hline 1 child & $4(21.1 \%)$ & $6(30 \%)$ & \\
\hline$\geq 2$ children & $3(15.8 \%)$ & $1(5 \%)$ & \\
\hline Number of night shifts* & $8.7 \pm 3.6$ & $6.8 \pm 4.2$ & $<0.01$ \\
\hline \multicolumn{4}{|c|}{$\begin{array}{l}\text { Distance between home and } \\
\text { work }^{\mathrm{a}}\end{array}$} \\
\hline Close & $19(100 \%)$ & 19 (95\%) & \multirow[t]{2}{*}{0.106} \\
\hline Distant & 0 & $1(5 \%)$ & \\
\hline \multicolumn{4}{|c|}{$\begin{array}{l}\text { Physical condition of working } \\
\text { environment }^{\mathrm{a}}\end{array}$} \\
\hline Perfect & $1(5.2 \%)$ & $2(10 \%)$ & \multirow[t]{3}{*}{0.563} \\
\hline Sufficient & $11(57.9 \%)$ & $8(40 \%)$ & \\
\hline Poor & 7 (36.9\%) & $10(50 \%)$ & \\
\hline \multicolumn{4}{|l|}{ Safety \& Security ${ }^{a}$} \\
\hline Very safe & $1(5.2 \%)$ & $2(10 \%)$ & \multirow[t]{3}{*}{0.505} \\
\hline Sufficient & $9(47.4 \%)$ & $7(35 \%)$ & \\
\hline Bad & $9(47.4 \%)$ & $11(55 \%)$ & \\
\hline \multicolumn{4}{|l|}{ Condition of the toilets ${ }^{a}$} \\
\hline Perfect & $2(10.5 \%)$ & $1(5 \%)$ & \multirow[t]{3}{*}{0.301} \\
\hline Sufficient & $12(63.2 \%)$ & $8(40 \%)$ & \\
\hline Bad & $5(26.3 \%)$ & $11(55 \%)$ & \\
\hline \multicolumn{4}{|l|}{ Skipping the meal time ${ }^{a}$} \\
\hline Often & $10(52.6 \%)$ & $10(50 \%)$ & \multirow[t]{3}{*}{0.027} \\
\hline Sometimes & $3(15.8 \%)$ & $8(40 \%)$ & \\
\hline Rarely & $6(31.6 \%)$ & $2(10 \%)$ & \\
\hline
\end{tabular}

${ }^{a}$ Categorical variables were expressed as absolute values and percentages.

${ }^{*}$ Data are presented as mean \pm standard deviation, where appropriate. 
were either from EM $(n=19 ; 48.7 \%)$, or from IM $(n=20 ; 51.3 \%)$. There were $17(43.6 \%)$ males and $22(56.4 \%)$ females with a mean age of $32.6 \pm 6.8$ years (range, 24-50 years). Considering the conditions of working environment and also socio demographic features there were no significant differences between two groups except number of night shifts and skipping the mealtime during work hours. While EM physicians had night shifts more frequently than IM physicians, by contrast IM physicians had skipped their mealtime more often than EM doctors. The sociodemographic characteristics and the factors that might affect the stress level of the participants are demonstrated in Table 1.

The PLSS scores of the participants ranged from 7 to 37 (mean 19.2 \pm 6.9 ). While 11 (28.2\%) participants had a score of $0-15$ points which indicated that stress was not a problem in their life, 26 (66.7\%) participants had a score of $16-30$ points indicating a moderate range of stress in their professional lives. Only $2(5.1 \%)$ physicians had a PLSS score of more than 30 points indicating that stress was plainly problem and need for curative action was apparent. The BAI and BDI scores of the participants ranged from 0 to 36 (mean, $8.4 \pm 8.9$ ) and 0 to 29 (mean, 7.6 \pm 5.9 ), respectively. AAQ-II scores, indicative of psychological inflexibility levels of the participants ranged from 7 to 39 (mean, $19.3 \pm 6.9$ ).

When the professions were compared in terms of scale scores, only AAQ-II scores were found significantly lower in emergency medicine specialists than the others $(p=0.049)$. On the contrary, there were no differences between EM and IM groups. Besides, no significant differences had been found between the professions in terms of PLSS, BAI and BDI scores (Table 2,3).

When the genders and the marital statuses were compared in terms of scale scores, it was determined that there was no significant difference between the gender, marital statuses in all scale scores. When the status of having children was

Table 2. AAQ-II scores of the participants according to their positions in departments.

\begin{tabular}{|c|c|c|c|c|c|c|c|c|}
\hline & \multirow[b]{2}{*}{ Position } & \multirow[b]{2}{*}{$\mathbf{N}$} & \multirow[b]{2}{*}{ Mean } & \multirow[b]{2}{*}{ Std. Deviation } & \multicolumn{3}{|c|}{ Percentiles } & \multirow[b]{2}{*}{$\mathbf{p}$} \\
\hline & & & & & 25 & Median & 75 & \\
\hline \multirow[t]{2}{*}{ Acceptance and Action } & IM Specialists & 10 & 17.4 & 8.0 & 11 & 14 & 23.5 & \\
\hline & IM Residents & 10 & 20.5 & 8.2 & 16.75 & 18 & 22 & \\
\hline \multirow[t]{2}{*}{ Questionnaire-II } & EM Specialist & 9 & 12.4 & 3.2 & 10 & 12 & 14.5 & $0.049^{*}$ \\
\hline & EM Resident & 10 & 19.4 & 8.8 & 11.75 & 19 & 25.25 & \\
\hline
\end{tabular}

IM: Internal Medicine, EM: Emergency Medicine

*There was significant statistical differences between EM Specialists and the other groups.

Table 3. The scores of the participants according to their departments.

\begin{tabular}{|c|c|c|c|c|c|c|c|c|}
\hline & \multirow[b]{2}{*}{ Department } & \multirow[b]{2}{*}{$\mathbf{N}$} & \multirow[b]{2}{*}{ Mean } & \multirow[b]{2}{*}{ SD } & \multicolumn{3}{|c|}{ Percentiles } & \multirow[b]{2}{*}{$\mathbf{p}$} \\
\hline & & & & & 25 & Median & 75 & \\
\hline \multirow[t]{2}{*}{ Beck Anxiety Inventory } & Internal Medicine & 20 & 9.3 & 9.7 & 3 & 6.5 & 12.75 & 0.461 \\
\hline & Emergency Medicines & 19 & 7.5 & 8.2 & 0 & 5 & 10 & \\
\hline \multirow{2}{*}{ Beck Depression Inventory } & Internal Medicine & 20 & 7.2 & 5.3 & 3.25 & 6 & 10.75 & 0.667 \\
\hline & Emergency Medicine & 19 & 8.0 & 6.5 & 4 & 7 & 11 & \\
\hline \multirow[t]{2}{*}{ Acceptance and Action Questionnaire-II } & Internal Medicine & 20 & 19.0 & 8.0 & 12.25 & 18 & 20.5 & 0.258 \\
\hline & Emergency Medicine & 19 & 16.1 & 7.5 & 11 & 13 & 20 & \\
\hline \multirow[t]{2}{*}{ Professional Life Stress Scale } & Internal Medicine & 20 & 19.3 & 6.5 & 15.25 & 19.5 & 23.75 & 0.813 \\
\hline & Emergency Medicine & 19 & 19.3 & 7.4 & 14 & 16 & 24 & \\
\hline
\end{tabular}


Table 4. Descriptive statistics of the scale scores according to the number of child.

\begin{tabular}{|c|c|c|c|c|c|c|c|c|}
\hline & \multirow[b]{2}{*}{ Number of child } & \multirow[b]{2}{*}{$\mathbf{N}$} & \multirow[b]{2}{*}{ Mean } & \multirow[b]{2}{*}{ Std. Deviation } & \multicolumn{3}{|c|}{ Percentiles } & \multirow[b]{2}{*}{$\mathbf{p}$} \\
\hline & & & & & 25 & Median & 75 & \\
\hline \multirow[t]{3}{*}{ Beck Anxiety Inventory } & Childless & 25 & 10.4 & 10.0 & 3 & 7 & 18 & \\
\hline & Single child & 10 & 5.1 & 5.4 & 1.5 & 4.5 & 6 & \multirow[t]{2}{*}{0.246} \\
\hline & $\geq 2$ children & 4 & 4.25 & 4.0 & .5 & 4 & 8.25 & \\
\hline \multirow[t]{3}{*}{ Beck Depression Inventory } & Childless & 25 & 8.9 & 6.4 & 5 & 7 & 12 & \\
\hline & Single child & 10 & 5.5 & 4.2 & 1.75 & 5 & 8.75 & \multirow[t]{2}{*}{0.152} \\
\hline & $\geq 2$ children & 4 & 4 & 4.1 & .25 & 4 & 7.75 & \\
\hline \multirow[t]{3}{*}{ Acceptance and Action Questionnaire-II } & Childless & 25 & 19.96 & 8.5 & 13.5 & 18 & 27 & \\
\hline & Single child & 10 & 14.1 & 3.8 & 11 & 12.5 & 18.25 & \multirow{2}{*}{0.028} \\
\hline & $\geq 2$ children & 4 & 11.25 & 1.7 & 9.5 & 11.5 & 12.75 & \\
\hline \multirow[t]{3}{*}{ Professional Life Stress Scale } & Childless & 25 & 21.68 & 6.5 & 16 & 22 & 26 & \multirow{3}{*}{0.019} \\
\hline & Single child & 10 & 15.8 & 5.7 & 11.75 & 16 & 21.5 & \\
\hline & $\geq 2$ children & 4 & 13 & 4.2 & 8.75 & 13.5 & 16.75 & \\
\hline
\end{tabular}

compared in terms of scale scores, the AAQII score of those with more than 2 children was significantly lower than those with no children $(p=0.028)$. In addition, the PLSS scores of those with more than 2 children or one child were significantly lower than those without children $(p=0.019)$. No significant difference was found between the number of children in terms of other scale scores (Table 4).

The relationship between scale scores and age, weekly working hours and monthly night shifts is

Table 5. Relation of the scale scores with each other and with age, weekly working hours, and number of monthly night shifts.

\begin{tabular}{lllllll}
\hline & & BDI & PLSS & Age & $\begin{array}{l}\text { Weekly } \\
\text { Working } \\
\text { Hours }\end{array}$ & $\begin{array}{l}\text { Number } \\
\text { of Night } \\
\text { Shifts }\end{array}$ \\
\hline \multirow{3}{*}{ BAI } & r & .561 & .608 & -.280 & .140 & .105 \\
& $\mathrm{P}$ & .000 & .000 & .084 & .395 & .524 \\
& $\mathrm{~N}$ & 39 & 39 & 39 & 39 & 39 \\
$\mathrm{BDI}$ & $\mathrm{r}$ & & .754 & -.283 & .064 & .215 \\
& $\mathrm{P}$ & & .000 & .081 & .698 & .190 \\
& $\mathrm{~N}$ & & 39 & 39 & 39 & 39 \\
AAQ-II & $\mathrm{r}$ & & .532 & -.447 & .069 & .047 \\
& $\mathrm{P}$ & .000 & .004 & .674 & .776 \\
PLSS & $\mathrm{N}$ & & 39 & 39 & 39 & 39 \\
& $\mathrm{r}$ & & & -.314 & .002 & .151 \\
& $\mathrm{~N}$ & & & .050 & .989 & .360 \\
& & & 39 & 39 & 39
\end{tabular}

BAI: Beck Anxiety Inventory; BDI: Beck Depression Inventory; AAQ-II: Acceptance and Action Questionnaire-II; PLSS: Professional Life Stress Scale given in Table 5 . When Table 5 is examined, it is seen that the significant relationships are stained in dark color and there is a significant negative relationship between age, AAQ-II and PLSS scores (rho: $-0.447 ; p=0.004$ and rho: $-0.314 ; p=0.05$, respectively).

\section{DISCUSSION}

Participating physicians in both emergency and internal departments had a moderate level of stress according to PLSS scores. According to PLSS scores, stress did not cause a problem in the lives of $28.2 \%$ of the participants, whereas stress was seen as a moderate problem in the lives of $66.7 \%$ of the participants. For only $5 \%$ of the participants, stress is obviously a problem and intervention is required in our study. In a recent study performed using PLSS scores, non-problematic (37.1\%), moderate $(52.1 \%)$ and severe $(10 \%)$ levels of stress were revealed in health care workers ${ }^{19}$. In another study conducted with nurses using PLSS scores, these rates were reported as $46 \%, 51 \%$ and $3 \%$ consecutively ${ }^{20}$. The fact that the participants exhibiting moderate stress in our study was higher than the other studies can be explained by two factors: One of these factors may be the small number of participants as stated in the limitations of the study. Another factor may be that the participants assessed in our study were physicians 
unlike other studies. Because, as shown in the literature, burnout and perceived stress are more prevalent in physicians working alone in decisionmaking position than in nurses working in groups not involved in decision-making process ${ }^{19,21}$.

Especially AAQ-II scores were significantly lower in emergency physicians which indicates they had a lower level of experiential avoidance (EA) and higher level of psychological flexibility (PF) than the others. EA has been broadly defined as attempts to avoid thoughts, feelings, memories, physical sensations, and other internal experience even though they will harm the psychologic well-being of the individual in the long run. Low level of EA shows that these participants are less engaged with negative internal processes than the individuals in the high level of EA group. It has been shown that AAQ-which is the most important measurement tool of PF-predicts a widerange of quality of life outcomes (e.g., depression, anxiety, general mental health, job satisfaction, future work absence, future job performance and perceived stress). In the light of this finding, we would expect to see a similar difference in professional stress levels between the two groups but we could not find a significant difference between the two groups in the terms of work-related stress. One explanation of this result may be the small number of participants in the study. Another factor may be the measurement properties of AAQ-II. Similar to our findings, in an interventional study conducted with professionals working in social organizations, positive improvement in stress and PF levels after intervention could not be demonstrated based on AAQ-II scale scores ${ }^{22}$. Although AAQ-II is widely used as a scale that reflects $\mathrm{PF}$ alone, some studies have claimed that AAQ-II failed to foresee PF, and other processes predicting PF should also be evaluated ${ }^{23,24}$. We believe that the results of our study will contribute to the ongoing discussions on AAQ-II.

However, in this study, there were no difference in BAI, BDI and PLSS scores between residents and physicians working in EM and IM. Professional knowledge and skills of residents are incomplete and job-control is not enough as the required expertise period has not yet been completed. In this sense, residents need assistance that will guide and support them to develop and increase their professionality. Previous studies have pointed that seniority, working with consultants, and feeling appreciated in work place are factors in resident's satisfaction or burnout status ${ }^{25,26}$. EM physicians who already might have suffered from some degree of sleep deprivation, experience stress from patients who require excessive focus and rapid decision-making in both critical and noncritical conditions $^{25,27}$.

When PLSS levels were compared by gender; it was noticed that male/female ratio was equal to 1 in moderate stress group. Accordingly, women and men are equally stressed in terms of of professional difficulties. Although the number of participants was lesser and not statistically significant, it was noteworthy that apparent stress group consisted of only 2 women. When AAQ-II scores of emergency physicians were significantly lower due to their different tasks they assumed, it was found that emergency physicians had lower levels of experiential avoidance and higher level of PF levels compared to internist. Another interesting result was detected in the relationship between PLSS and PF. It was shown that PF scores were higher and PLSS scores were lower in study participants with children. Similar results are emphasized in the literature on the relationship between professional burnout and having children ${ }^{28-30}$. Considering that PLSS and occupational burnout are similar phenomena, it can be said that the results of our study are consistent with the literature.

In our study, it was shown that there was a positive linear relationship between depression and anxiety levels and PLSS. Similarly, a positive linear correlation was found between the increase in AAQ scores, which is one of the strong predictors 
of PF, and PLSS. The PLSS scores of the group with higher AAQ-II scores, i.e. lower PF, reached 20.8, indicating a moderate level of stress in a hard working person, and attempts to reduce stress according to the scale were found to exert beneficial effects. The mean PLSS score was 14.1 in the group with AAQ-II scores were below the average, which was interpreted as the level of stress that did not cause a problem in professional life. Correlation analysis and independent samples Ttest demonstrated a linear correlation between PF and PLSS. Although there are few studies examining the relationship between PF and stress brought about by business life, it has been shown that approaches that increase PF level decrease the stress level in the work environment as reveled in interventional studies ${ }^{31,32}$.

The results of regression analysis show that the increase in depression and anxiety levels aggravates professional life stress. However, in the analysis, it is seen that AAQ-II, which is one of the best expressions of $\mathrm{PF}$, is not a predictive factor in PLSS. In our study, PF was evaluated with AAQII scale only. Studies with other scales evaluating other parametres of PF, such as contact values, self-perception, and AAQ-II, which mostly indicate experiential avoidance, will reveal the relationship between PF and PLSS ${ }^{33}$.

\section{CONCLUSION}

This study shows that emergency department employees are less engaged with their negative internal experiences than internal medicine polyclinic employees. We can say that working in EM departments for longer periods is associated with higher stress levels increasing the ability to cope with stress. Another outcome of study is that having children is related with low AAQ-II scores which indicate higher levels of PF, hence decrease in experiential avoidance. In addition, further studies with larger groups will contribute to clarifying the relationship between PF and PLSS.

\section{LIMITATIONS}

The findings of this study have to be considered in the light of some limitations. One of the major limitation is the sample size of the study; as we mentioned in the discussion section, the small number of participants affected some statistical results. Another limitation is the failure to focus on the professional experience (years) of the participants. We didn't evaluate the participants' stress based on the years of working experience. Because it is known that the severity of professional burnout and perceived stress decrease with increased working experience. We believe that the further studies including professional experience and other processes of PF in greater number of participants will lead us to new results.

\section{REFERENCES}

1. Tutar H. Kriz ve stres ortamında yönetim, Hayat Yayınları, Yayın no:88, İstanbul, 2000.

2. Halder S, Mahato AK. Stress and psychological well being status among health care professionals. Int J Occup Safety Health. 2013;3:32-5. [CrossRef]

3. McManus IC, Winder BC, Gordon D. The causal links between stress and burnout in a longitudinal study of UK doctors. Lancet. 2002 Jun 15;359(9323):2089-90. [CrossRef]

4. Isenberg DL, Van Gelder CM. Occupational illness and injury in 25. prehospital care personnel. In: Greenberg MI, ed. Occupational Emergency Medicine. Oxford, UK: Wiley-Blackwell, 2011, p. 162-74. [CrossRef]

5. Kocak M, Gul OA, Aydın H, Aciksari K, Ozucelik DN. Frequency of anxiety among physicians working in emergency departments and other clinics in Turkey: A crosssectional survey. Medeniyet Med J. 2019;34:135-42. [CrossRef]

6. Young KM, Cooper CL. Occupational stress in the ambulance service: a diagnostic study. Health Manpow Manage. 1997;23:140-7.

7. Sterud T, Hem E, Lau B, Ekeberg O. A comparison of general and ambulance specific stressors: predictors of job satisfaction and health problems in a nationwide oneyear follow-up study of Norwegian ambulance personnel. J Occup Med Toxicol. 2011;6:10. [CrossRef]

8. van der Ploeg E, Kleber RJ. Acute and chronic job stressors among ambulance personnel: predictors of health symptoms. Occup Environ Med. 2003;60 Suppl 1:i40-6. [CrossRef]

9. Mitchell JT. When disaster strikes...the critical incident stress debriefing process. JEMS. 1983;8:36-9.

10. Price JL, Mueller CW. Professional turnover: the case of nurses. Health Syst Manage. 1981;15:1-160. [CrossRef]

11. Cronin-Stubbs D, Brophy EB. Burnout. Can social support save the psych nurse? J Psychosoc Nurs Ment Health 
Serv. 1985;23:8-13.

12. O'Connor K, Muller Neff D, Pitman S. Burnout in mental health professionals: A systematic review and metaanalysis of prevalence and determinants. Eur Psychiatry. 2018;53:74-99. [CrossRef]

13. The British Psychological Society and Routledge Ltd, Leicester, England, 1989.

14. Beck AT, Epstein N, Brown G, Steer RA. An inventory for measuring clinical anxiety: psychometric properties. J Consult Clin Psychol. 1988;56:893-7. [CrossRef]

15. Ulusoy M, Sahin NH, Erkmen H. Turkish version of the Beck Anxiety Inventory. J Cogn Psychother 1998;12:16372.

16. Beck AT, Steer RA, Carbin MG. Psychometric properties of the Beck Depression Inventory: Twenty-five years of evaluation. Clin Psychol Rev. 1988;8:77-100. [CrossRef]

17. Hisli N. Beck Depresyon envanterinin üniversite öğrencileri için geçerliliği, güvenirliği. Psikoloji Dergisi. 1989;7:3-13.

18. Yavuz F, Ulusoy $S$, Iskin $M$, et al. Turkish version of acceptance and action questionnaire-II (AAQ-II): A reliability and validity analysis in clinical and non-clinical samples. Bull Clin Psychopharmacol. 2016;26:397-408. [CrossRef]

19. Sagar S, Ravish KS, Ranganath TS, Ahmed MT, Shanmugapriya D. Professional stress levels among healthcare workers of Nelamangala: a cross sectional study. Int J Community Med Public Health. 2017;4:4685-91. [CrossRef]

20. Sharma P, Davey A, Davey S, Shukla A, Shrivastava K, Bansal R. Occupational stress among staff nurses: Controlling the risk to health. Indian J Occup Environ Med. 2014;18:52-6. [CrossRef]

21. Baranik LE, Wang M, Gong Y, Shi J. Customer mistreatment, employee health, and job performance: Cognitive rumination and social sharing as mediating mechanisms. J Management. 2017;43:1261-82. [CrossRef]

22. Brinkborg H, Michanek J, Hesser H, Berglund G. Acceptance and commitment therapy for the treatment of stress among social workers: a randomized controlled trial. Behav Res Ther. 2011;49:389-98. [CrossRef]

23. Bond FW, Hayes SC, Baer RA, et al. Preliminary psychometric properties of the Acceptance and Action Questionnaire-II: a revised measure of psychological inflexibility and experiential avoidance. Behav Ther. 2011;42:67688. [CrossRef]

24. Wolgast $M$. What does the Acceptance and Action Questionnaire (AAQ-II) really measure? Behav Ther. 2014;45:831-9. [CrossRef]

25. Bragard I, Dupuis G, Fleet R. Quality of work life, burnout, and stress in emergency department physicians: a qualitative review. Eur J Emerg Med. 2015;22:227-34. [CrossRef]

26. Gross R, Tabenkin H, Brammli-Greenberg S. Factors affecting primary care physicians' perceptions of health system reform in Israel: professional autonomy versus organizational affiliation. Soc Sci Med. 2007;64:1450-62. [CrossRef]

27. Estryn-Behar M, Doppia MA, Guetarni K, et al. Emergency physicians accumulate more stress factors than other physicians-results from the French SESMAT study. Emerg Med J. 2011;28:397-410. [CrossRef]

28. Ndetei DM, Pizzo M, Maru H, et al. Burnout in staff working at the Mathari psychiatric hospital. Afr J Psychiatry (Johannesbg). 2008;11:199-203. [CrossRef]

29. Maslach C, Jackson SE. The role of sex and family variables in Burnout. Sex Roles. 1985;12:837-51. [CrossRef]

30. Ayala E, Carnero AM. Determinants of burnout in acute and critical care military nursing personnel: a crosssectional study from Peru. PLoS One. 2013;8:e54408. [CrossRef]

31. Wardley MNj, Flaxman PE, Willig C, Gillanders D. 'Feel the Feeling': Psychological practitioners' experience of acceptance and commitment therapy well-being training in the workplace. J Health Psychol. 2016;21:1536-47. [CrossRef]

32. Bond FW, Flaxman PE, Lloyd J. Mindfulness and meditation in the workplace: An acceptance and commitment therapy approach. In: Michael A. West, ed. The Psychology of Meditation, Research and Practice. Oxford University Press. 2016. [CrossRef]

33. Hayes SC, Wilson KG, Gifford EV, Follette VM, Strosahl K. Experimental avoidance and behavioral disorders: a functional dimensional approach to diagnosis and treatment. J Consult Clin Psychol. 1996;64:1152-68. [CrossRef] 